\title{
Reproductive effects of immunizing heifers against androstenedione and oestradiol-17 $\beta$
}

\author{
T. H. Wise and B. D. Schanbacher \\ U.S. Department of Agriculture, Agricultural Research Service, U.S. Meat Animal Research Center, \\ P.O. Box 166, Clay Center, Nebraska 68933, U.S.A.
}

\begin{abstract}
Summary. Heifers were treated with saline (Group I, $N=10$ ), keyhole limpet haemocyanin (KLH; Group II, N = 10), androstenedione-KLH antigen (Group III, N $=14$ ), or oestradiol-17ß-KLH antigen (Group IV, $N=14$ ). Booster injections were given to produce binding of $>10 \%$ at dilutions of $1: 100$ to $1: 1000(50 \%$ binding $=$ $14.4 \mathrm{pg}$ androstenedione and $9.5 \mathrm{pg}$ oestradiol). The heifers were mated and killed at $\sim 46$ days of gestation to establish ovulation rates, calf numbers, blood hormone relationships and ovarian morphology.

Ovulation rate in animals immunized against androstenedione (Group III) was significantly greater than in the other groups; 4 of the animals had double ovulations and 3 had twins. No significant differences were found between Groups I, II and IV in relation to ovulation or pregnancy rate and animals immunized against oestradiol-17 $\beta$ continued to cycle and become pregnant. Systemic progesterone, androstenedione and oestrogen levels were generally increased in Groups III and IV but the differences were not significant. No differences were detected between treatment groups in relation to $\mathrm{CL}$ weights, ovarian weights, follicle sizes or numbers. No binding of $\left[{ }^{3} \mathrm{H}\right]$ androstenedione or $\left[{ }^{3} \mathrm{H}\right]$ oestradiol- $17 \beta$ was detected in allantoic or amniotic fluids or fetal serum. Maternal antibody binding was correlated with binding of $\left[{ }^{3} \mathrm{H}\right]$ androstenedione and $\left[{ }^{3} \mathrm{H}\right]$ oestradiol in the follicular fluid sampled from the two largest follicles in the ovaries of each animal (Group III, $r=0.59$; Group IV, $r=0.60 ; P<0.05$ ). The response of increased ovulation rate in cattle immunized against androstenedione should be further investigated to study follicular recruitment and increased productivity.
\end{abstract}

\section{Introduction}

Studies of ewes actively immunized against androstenedione have shown that there are increases in follicular development, ovulation rate and lamb crops (Scaramuzzi, Davidson \& Van Look, 1977; Van Look, Clarke, Davidson \& Scaramuzzi, 1978; Scaramuzzi, Baird, Clarke, Martensz \& Van Look, 1980a), but the increases in ovulation rate may not always reflect increases in birth numbers due to possible anovulatory or anoestrous ewes and increased fetal wastage (Smith, Cox, McGowan, Wilson \& Hoskinson, 1981). Immunization of ewes against oestrogens can produce a castration-like effect upon pituitary function and block or delay ovulation (Scaramuzzi et al., 1977; Pant, Dobson \& Ward, 1978; Rawlings, Kennedy \& Henricks, 1978; Martensz, Scaramuzzi \& Van Look, 1979), quickly rendering the animal anovulatory (Scaramuzzi, 1975; Cox \& Wilson, 1976; Scaramuzzi et al., 1977). The prevention of oestrus and ovulation by circulating antibodies to oestrogens has also been noted in other species (Sundaram, Tsong, Hood \& Brinson, 1973; Ferin, Dyrenfurth, Cowchock, Warren \& Vande Wiele, 1974; Elsaesser \& Parvizi, 1977; Martin, Henricks, Hill \& Rawlings, 1978; Elsaesser, 1980). Nevertheless, the increases in ovulation and 
lambing rates after immunization of sheep against oestrogens have been reported (Smith et al., 1981 ; Land, Morris, Baxter, Fordyce \& Forster, 1982). Since active or passive immunization with steroid hormones is now being considered for practical applications, the objectives of this study were to document the reproductive effects of active immunization of beef cattle against androstenedione and oestradiol-17 $\beta$ (oestradiol) in relation to ovulation rates, conception rate, blood steroid hormones and ovarian morphology.

\section{Materials and Methods}

Immunization procedure. Forty-eight (48) normally cyclic crossbred heifers of 12-14 months of age (1/2 Simmental, 1/4 Hereford, 1/4 Angus, Hereford or Red Poll) were randomly allocated to 4 groups: Group I ( $\mathrm{N}=10)$ contained controls injected with $1 \mathrm{ml}$ saline $(9 \mathrm{~g} \mathrm{NaCl} / 1)$; Group II $(\mathrm{N}=$ 10) contained animals actively immunized against the immunogenic carrier protein, keyhole limpet haemocyanin (KLH, Calbiochem, La Jolla, California, U.S.A.); Group III (N = 14) animals were immunized against 4-androsten-6 $\beta$-ol-3,17,dione hemisuccinate (Steraloids Inc., Wilton, New Hampshire, U.S.A.) conjugated to KLH; and Group IV (N = 14) animals were immunized against 1,3,5(10)-oestratrien-3,17 $\beta$-diol-6-one carboxymethoxime (Steraloids Inc.) conjugated to KLH. Steroids were coupled to KLH by the carbodiimide method of Goodfriend, Levine \& Fasman (1964). Animals were injected at the rear attachment of the mammary gland and along the tailhead with $5 \mathrm{mg}$ antigen in $1 \mathrm{ml}$ Freund's complete adjuvant:saline $(1: 1 \mathrm{v} / \mathrm{v})$ and $0.5 \mathrm{ml}$ each of diphtheria, tetanus and pertussis toxoids (Wyeth Lab., Marietta, Pennsylvania, U.S.A.) at the initial immunization. Two 1-mg booster injections were given in Freund's incomplete adjuvant at 30-day intervals. At the time of the last booster, bulls $(N=4)$ were placed with the heifers for 56 days. The heifers were then killed to determine ovulation and pregnancy rate.

Sample collection. Jugular blood samples were collected from each animal at the time of immunization and slaughter. At slaughter, ovaries and corpora lutea (CL) were weighed. Antral surface follicles were counted and the diameter measured with calipers. Follicular fluid was aspirated from the 2 largest follicles of each animal. Allantoic and amniotic fluids $(5 \mathrm{ml})$ and fetal blood serum were also sampled for future analysis. Samples were centrifuged $(2000 \mathrm{~g}, 30 \mathrm{~min})$, and the supernatant aspirated and frozen at $-20^{\circ} \mathrm{C}$ until assayed. Fetal crown-rump lengths were measured to determine the stage of gestation.

Assay procedure. The antiserum binding titres were measured at each successive booster injection by incubating aliquants of diluted serum $(1: 100,1: 1000$ and $1: 10000)$ with 20000 d.p.m. $\left[1,2,6,7-{ }^{3} \mathrm{H}\right]$ androstenedione (sp. act. $90 \mathrm{Ci} / \mathrm{mmol}$ : New England Nuclear Corp., Boston, Massachusetts, U.S.A.) or 20000 d.p.m. $\left[1,2,6,7,16,17-{ }^{3} \mathrm{H}\right]$ oestradiol-17 $($ sp. act. $137 \mathrm{Ci} / \mathrm{mmol}$; New England Nuclear) in a dextran-charcoal radioassay. Follicular fluid binding of $\left[{ }^{3} \mathrm{H}\right]$ androstenedione and $\left[{ }^{3} \mathrm{H}\right]$ oestradiol was measured at $1: 100$ and $1: 1000$ dilution without charcoal extraction of endogenous steroids. Antiserum affinity constants were calculated by Scatchard plots (Scatchard, 1949) as modified by Chamness \& McGuire (1975). Cross-reactivity (tested as described by Abraham, 1974) of the pooled antisera was tested against various steroids purchased from Steraloids Inc. Moxoestriol [1,3,5(10)-oestratrien-17 $\alpha$-ethinyl-11 $\beta$-methoxy-3,17-diol] was purchased from New England Nuclear.

Steroids were extracted ( 3 times) from $5 \mathrm{ml}$ serum with $15 \mathrm{ml}$ diethyl ether to ensure adequate recovery. Before extraction $\left[{ }^{14} \mathrm{C}\right]$ androstenedione (approximately 1000 c.p.m.), $\left[{ }^{14} \mathrm{C}\right]$ progesterone and $\left[{ }^{14} \mathrm{C}\right]$ oestradiol-17 3 (New England Nuclear) were added to estimate procedural losses. Average recovery for progesterone, androstenedione and oestradiol were 83,73 and $70 \%$, respectively. Samples were dried under nitrogen after ether extraction and submitted to Sephadex LH-20 chromatography (Wise, Caton, Thatcher, Barron \& Fields, 1982a) which separated progesterone from androstenedione and the total oestrogens were washed from the column $(0.5 \times 14 \mathrm{~cm}$, cyclohexane : benzene : methanol, $90: 10: 5$, by vol.). The assays for progesterone and androstene- 
dione were modified from those described by Wise et al. (1982a) and Wise, Caton, Thatcher, Leher $\&$ Fields (1982b). The progesterone antiserum was rabbit anti-progesterone-11 $\alpha$-bovine serum albumin and the androstenedione antiserum was rabbit anti-androstenedione-7 $\alpha$-BSA (Miles Yeda Ltd, Rehovot, Israel). The assay for total oestrogens was modified from that of Ford, Christenson \& Ford (1982) in that oestrone and oestradiol were pooled for assay purposes after Sephadex LH-20 chromatography. The oestrogen antibody was made against oestriol-3,16 $3,17 \beta-$ trihemisuccinate-human serum albumin in sheep (purchased from G. Abraham, Torrance, California) and cross-reacted $100 \%$ with oestrone and oestradiol.

The characteristics of the assays were as follows:

$\begin{array}{lccc} & \text { Limit of sensitivity Inter-assay } \\ (\mathrm{pg} / \mathrm{ml}) & \begin{array}{c}\text { Antiserum } \\ \text { variation }\end{array} \\ \text { Progesterone } & \text { PR-2 } & 500 & 15 \cdot 7 \% \\ \text { Androstenedione } & \text { AT-3 } & 15 & 14.0 \% \\ \text { Oestradiol-17 } \beta & \text { S-310 No. 5 } & 5 & 16.0 \%\end{array}$

The assay variation and accuracy for progesterone, androstenedione and oestradiol were determined from 10 ovariectomized plasma samples $(5 \mathrm{ml})$ spiked with progesterone $(1000 \mathrm{pg} / \mathrm{ml})$, androstenedione $(50.0 \mathrm{pg} / \mathrm{ml})$ and oestradiol $(5.0 \mathrm{pg} / \mathrm{ml})$ that were extracted, chromatographed and assayed with the serum samples from the study. Mean \pm s.e.m. values measured for progesterone, androstenedione and oestradiol were $1034 \pm 51 \cdot 4,55.5 \pm 2.4$ and $5.5 \pm 0.22 \mathrm{pg} / \mathrm{ml}$, respectively.

Statistical procedures. Analysis of ovulation and pregnancy rates between treatments was by a two-way $\chi^{2}$ analysis (treatment versus ovulation rate). Other reproductive characteristics were assessed by analysis of variance to determine the effects of treatment (immunized and nonimmunized), pregnancy and the interaction of these variables. Differences between two means were determined by Student's $t$ test.

\section{Characterization of the antiserum}

\section{Results}

The androstenedione antiserum (Group III) bound $2.38 \pm 0.02 \%, 17.04 \pm 0.03 \%$ and $15.78 \pm$ $0.03 \%$ (mean \pm s.e.m.) on the first, second and final sampling (at the first booster, second booster and slaughter; $1: 100$ dilution, $14.4 \mathrm{pg}\left[{ }^{3} \mathrm{H}\right]$ androstenedione $=50 \%$ ). The oestradiol antiserum (Group IV) exhibited $7 \cdot 9 \pm 3 \cdot 2 \%, 55 \cdot 1 \pm 5 \cdot 9 \%$ and $39.6 \pm 2 \cdot 6 \%$ binding ( $1: 100$ dilution; $9 \cdot 5 \mathrm{pg}$ $\left[{ }^{3} \mathrm{H}\right]$ oestradiol $=50 \%$ ). Cross-reactivity of the pooled antisera from animals immunized against anti-androstenedione (1:100 dilution; $15 \cdot 7 \%$ binding) and anti-oestradiol (1:1000 dilution; $17.6 \%$ binding) is listed in Table 1. Scatchard analysis of antiserum demonstrated an average (range)

Table 1. Cross-reactivity of pooled antisera produced in heifers immunized against androstenedione and oestradiol- $17 \beta$

\begin{tabular}{lcc}
\hline & \multicolumn{2}{c}{ Cross-reactivity $(\%)^{*}$} \\
\cline { 2 - 3 } & $\begin{array}{c}\text { Anti-androstenedione } \\
(1: 100)\end{array}$ & $\begin{array}{c}\text { Anti-oestradiol } \\
(1: 1000)\end{array}$ \\
\hline Androstenedione & 100.0 & $<1.0$ \\
Testosterone & $<1.0$ & $<1.0$ \\
Oestrone & 5.0 & 5.4 \\
Oestradiol & $<1.0$ & 100.0 \\
Diethylstilboestrol & $<1.0$ & $<1.0$ \\
Moxoestriol & $<1.0$ & $<1.0$ \\
\hline
\end{tabular}

* Determined by mass of steroid required for $50 \%$ displacement of $\left[{ }^{3} \mathrm{H}\right]$ androstenedione or $\left[{ }^{3} \mathrm{H}\right]$ oestradiol. 
affinity association constant $\left(K_{\mathrm{a}}\right)$ for androstenedione of $113 \times 10^{7}\left(14-600 \times 10^{7} 1 / \mathrm{mol} ; 1: 20\right)$ and for oestradiol $215 \times 10^{7}\left(13-680 \times 10^{7} 1 / \mathrm{mol} ; 1: 20\right)$ when incubated with various amounts of [ ${ }^{3} \mathrm{H}$ ]androstenedione $\left(15-1000 \mathrm{pg}\right.$ ) and oestradiol $(15-1000 \mathrm{pg})$. The $K_{\mathrm{a}}$ of antisera from animals immunized against androstenedione and oestradiol was higher in non-pregnant animals but the differences were not significant $(P>0 \cdot 1$; Table 3$)$.

Incubation of $\left[{ }^{3} \mathrm{H}\right]$ oestradiol with serum from animals immunized against androstenedione and $\left[{ }^{3} \mathrm{H}\right]$ androstenedione with serum from animals immunized against oestradiol exhibited binding no different from that of control animals (Table 3). No binding of $\left[{ }^{3} \mathrm{H}\right]$ androstenedione or $\left[{ }^{3} \mathrm{H}\right]$ oestradiol was noted for any groups when fetal blood serum, allantoic or amniotic fluids were analysed $(1: 10,1: 100,1: 1000$ dilutions).

\section{Reproductive effects}

Ovulation rate was increased $(0.05<P<0.06)$ in the group immunized against androstenedione (Table 2), although no other differences in ovarian or hormonal characteristics were detected (Table 3 ) between treatment groups. The heifers were $46.7 \pm 3.7$ days pregnant at slaughter, with $65 \%$ of the animals being mated within the first oestrous cycle. The three sets of twins in Group III were all from two ovulations (two CL) and were of the same sex in only heifer. Animals immunized against oestradiol continued to cycle and become pregnant. Pregnancy rate or calving numbers were not significantly different between groups due to the small numbers involved, but animals immunized against androstenedione did have higher calf numbers $(100 \%$ compared with $80 \% ; P>0 \cdot 1$ ) than other groups (Table 2). In Group III, 3 heifers had twins (21\%) and 4 had double ovulations $(29 \%)$. One animal in Group II had twins and partly reflects the probable twinning rate of the Simmental breeding in these animals [Simmental herd twinning rate $=\sim 5 \%(25 / 525)$; total twinning rate for breeding animals $=<1 \%(40 / 5000)$; at the research centre]. There was no trend noted between ovulation rate and antibody binding in Group III but those heifers that became pregnant had significantly lower antibody binding $(P<0.05)$. No significant differences were noted between treatment groups in relation to follicular sizes or numbers. Corpora lutea or ovarian weights were not different across groups (Table 3). Peripheral oestrogen levels were correlated with the diameter of medium (5-9 mm diam.; $n=48)$ and large $>10 \mathrm{~mm}$ diam.; $n=48)$ sized follicles $(r=0.28$ and $0.37, P<0.05)$ from the ovaries of all animals.

Table 2. Comparison of fertility and fecundity in heifers of Group I (saline), Group II (keyhole limpet haemocyanin), Group III (androstenedione-keyhole limpet haemocyanin antigen), and Group IV (oestradiol$17 \beta$-keyhole limpet haemocyanin antigen)

\begin{tabular}{|c|c|c|c|c|}
\hline & Group I & Group II & Group III & Group IV \\
\hline \multicolumn{5}{|l|}{ Ovulation rate $\dagger$} \\
\hline Pregnant animals & $1 \cdot 0(8 / 8)$ & $1 \cdot 1(8 / 7)$ & $1 \cdot 36(15 / 11)$ & $1.0(11 / 11)$ \\
\hline Overall total & $1 \cdot 0(10 / 10)$ & $1 \cdot 1(11 / 10)$ & $1.29(18 / 14)^{*}$ & $0.93(13 / 14)$ \\
\hline \multicolumn{5}{|l|}{ Pregnancy rate } \\
\hline Overall total & $80 \%(8 / 10)$ & $70 \%(7 / 10)$ & $79 \%(11 / 14)$ & $79 \%(11 / 14)$ \\
\hline \multicolumn{5}{|l|}{ Calves/cow } \\
\hline Pregnant animals & $1 \cdot 0(8 / 8)$ & $1 \cdot 1(8 / 7)$ & $1 \cdot 27(14 / 11)$ & $1.0(11 / 11)$ \\
\hline Overall total & $0.8(8 / 10)$ & $0 \cdot 8(8 / 10)$ & $1 \cdot 0(14 / 14)$ & $0.79(11 / 14)$ \\
\hline
\end{tabular}

Values are means with the total no. and no. of animals in parentheses.

$* 0.05<P<0.06$ compared with other groups.

$\dagger$ No. of corpora lutea.

Maternal serum binding of $\left[{ }^{3} \mathrm{H}\right]$ androstenedione from the animals immunized against androstenedione (Group III) was positively correlated with follicular fluid binding from the two largest follicles $(r=0.59, P<0.05)$ in the ovaries. Maternal serum and follicular fluid anti- 
Table 3. Comparison of ovarian and hormonal indicators for heifers in Group I (saline), Group II (keyhole limpet haemocyanin), Group III (androstenedione-keyhole limpet haemocyanin antigen), and Group IV (oestradiol-17ß-keyhole limpet haemocyanin antigen)

\begin{tabular}{|c|c|c|c|c|}
\hline & Group I & Group II & Group III & Group IV \\
\hline \multicolumn{5}{|l|}{ Wt of ovaries (g) } \\
\hline Pregnant & $18.78 \pm 1 \cdot 3$ & $21 \cdot 2 \pm 1 \cdot 0$ & $18 \cdot 5 \pm 1 \cdot 0$ & $20 \cdot 6 \pm 1 \cdot 7$ \\
\hline Non-pregnant & $17.45 \pm 1.6$ & $29.0 \pm 8.5$ & $22 \cdot 3 \pm 3 \cdot 8$ & $20 \cdot 4 \pm 8 \cdot 1$ \\
\hline \multicolumn{5}{|l|}{ Wt of CL $(\mathrm{g})$} \\
\hline Pregnant & $5 \cdot 1 \pm 0 \cdot 3$ & $5 \cdot 7 \pm 0.5$ & $6 \cdot 0 \pm 0 \cdot 3$ & $6 \cdot 8 \pm 0.5^{*}$ \\
\hline Non-pregnant & $5.6 \pm 0.9$ & $5.8 \pm 1.2$ & $5.6 \pm 0.4$ & $2 \cdot 25 \pm 1 \cdot 1$ \\
\hline \multicolumn{5}{|c|}{ No. of small follicles, $\leq 4 \mathrm{~mm}$ diam. } \\
\hline Pregnant & $54 \cdot 0 \pm 10 \cdot 0$ & $52 \cdot 0 \pm 10 \cdot 4$ & $42 \cdot 8 \pm 0 \cdot 3$ & $50 \cdot 1 \pm 12 \cdot 2$ \\
\hline Non-pregnant & $31 \cdot 0 \pm 3 \cdot 0$ & $57 \cdot 0 \pm 26 \cdot 6$ & $35 \cdot 3 \pm 4 \cdot 6$ & $32.0 \pm 1.5$ \\
\hline \multicolumn{5}{|c|}{ No. of medium follicles, 5-9 mm diam. } \\
\hline Pregnant & $2.9 \pm 0.8$ & $3.4 \pm 1.6$ & $2 \cdot 5 \pm 0.6$ & $2 \cdot 2 \pm 0.5^{*}$ \\
\hline Non-pregnant & $4 \cdot 0 \pm 0.0$ & $7 \cdot 0 \pm 2.5$ & $3 \cdot 0 \pm 1 \cdot 0$ & $10 \cdot 3 \pm 8 \cdot 4$ \\
\hline \multicolumn{5}{|c|}{ No. of large follicles, $\geq 10 \mathrm{~mm}$ diam. } \\
\hline Pregnant & $2.3 \pm 0.05$ & $1.8 \pm 0.5$ & $2.5 \pm 0.4$ & $2.3 \pm 0.4$ \\
\hline Non-pregnant & $2 \cdot 0 \pm 1 \cdot 0$ & $2 \cdot 3 \pm 0.9$ & $2 \cdot 3 \pm 1 \cdot 3$ & $3 \cdot 0 \pm 1.5$ \\
\hline \multicolumn{5}{|c|}{ Systemic progesterone $(\mathrm{ng} / \mathrm{ml})$} \\
\hline Pregnant & $4.6 \pm 0.7$ & $4 \cdot 2 \pm 0.7$ & $6 \cdot 4 \pm 1 \cdot 1$ & $5.6 \pm 0.8$ \\
\hline Non-pregnant & $2.9 \pm 0.9$ & $5 \cdot 2 \pm 2 \cdot 5$ & $4.2 \pm 0.2$ & $3.4 \pm 0.5$ \\
\hline \multicolumn{5}{|c|}{ Systemic androstenedione $(\mathrm{pg} / \mathrm{ml})$} \\
\hline Pregnant & $55.6 \pm 5.4$ & $49.9 \pm 6.2$ & $72 \cdot 0 \pm 3 \cdot 0$ & $71 \cdot 3 \pm 20 \cdot 3$ \\
\hline Non-pregnant & $69.8 \pm 0.7$ & $64.5 \pm 12 \cdot 4$ & $64 \cdot 1 \pm 1 \cdot 6$ & $66 \cdot 8 \pm 15 \cdot 1$ \\
\hline \multicolumn{5}{|c|}{ Systemic oestrogens $(\mathrm{pg} / \mathrm{ml})$} \\
\hline Pregnant & $5 \cdot 1 \pm 0.9$ & $3.7 \pm 0.7$ & $4.7 \pm 0.8$ & $4.1 \pm 0.6$ \\
\hline Non-pregnant & $4 \cdot 6 \pm 3 \cdot 2$ & $3.7 \pm 0.6$ & $5.8 \pm 0.8$ & $7 \cdot 0 \pm 2.6$ \\
\hline \multicolumn{5}{|c|}{ Anti-androstenedione binding $(1: 10 \overline{0})$} \\
\hline Pregnant & $<1 \%$ & $<1 \%$ & $11.7 \pm 1.7 \% \%^{*} \dagger$ & $<1 \%$ \\
\hline Non-pregnant & $<1 \%$ & $<1 \%$ & $30 \cdot 3 \pm 4.6 \% \dagger$ & $<1 \%$ \\
\hline \multicolumn{5}{|c|}{ Anti-oestradiol binding $(1: 100)$} \\
\hline Pregnant & $<1 \%$ & $<1 \%$ & $<1 \%$ & $34 \cdot 1 \pm 4 \cdot 1 \% \dagger$ \\
\hline Non-pregnant & $<1 \%$ & $<1 \%$ & $<1 \%$ & $45.3 \pm 4.3 \% \dagger$ \\
\hline \multicolumn{5}{|c|}{ Anti-androstenedione $K_{3}\left(10^{7} 1 / \mathrm{mol}\right)$} \\
\hline Pregnant & - & _- & $70 \pm 17 \cdot 2$ & - \\
\hline Non-pregnant & - & - & $242 \pm 179 \cdot 0$ & - \\
\hline \multicolumn{5}{|c|}{ Anti-oestradiol $\mathrm{K}_{\mathrm{a}}\left(10^{7} \mathrm{l} / \mathrm{mol}\right)$} \\
\hline Pregnant & - & - & - & $175 \cdot 6 \pm 61 \cdot 1$ \\
\hline Non-pregnant & - & - & - & $347.6 \pm 171.6$ \\
\hline
\end{tabular}

Values are mean \pm s.e.m. for the no. of animals indicated in Table 2.

*Values significantly different from that for non-pregnant animals, $P<0.05$.

$\dagger$ Values significantly different from those for the other groups, $P<0.05$.

androstenedione binding revealed a correlation of $0.71(P<0.05)$ with the size (diameter) of the largest follicle in the ovary, but no relationship with size when compared to the next to largest follicle $(P>0 \cdot 1)$. Maternal serum anti-androstenedione binding was also correlated with ovarian weight $(r=0.56 ; P<0.05)$.

In the animals immunized against oestradiol (Group IV), maternal serum antibody binding of $\left[{ }^{3} \mathrm{H}\right]$ oestradiol was correlated with follicular fluid binding $(r=0.6 ; P<0.02)$; the latter had a correlation of $0.73(P<0.05)$ with the next to largest follicle in the ovaries of each cow, but no correlation with the largest follicle.

\section{Discussion}

These results for cattle, as in sheep, provide evidence that immunization against steroid hormones has considerable potential for increasing ovulation and calving rates although the mechanism is unknown. This study provides the first evidence that immunization of cattle against 
androstenedione does increase ovulation rate and calving rate similar to that demonstrated in sheep. Low rates of ovulation are a major limitation to increased productivity in cattle (although subsequent management practices for twins are uncertain). A modest increase in ovulation rate in cattle with a simple procedure could lead to increased numbers of live births per animal mated. Present techniques of superovulation via exogenous gonadotrophins to induce multiple ovulations are expensive, labour intensive, highly variable and difficult to apply on a large scale. In-vitro fertilization of superovulated eggs and subsequent transfer ( 2 embryos) to recipients may be a step towards increasing productivity, but this approach is still expensive and labour intensive. The practice of immunizing against androstenedione seems to have the further advantage in that ovulation rate is kept to 2 or 3 in ewes and 2 in cattle so that an excess of embryos is avoided.

Studies of ewes have demonstrated that immunization against androstenedione produces changes in the hypothalamic-pituitary-ovarian feedback and implies androstenedione is an active contributor to steroidal feedback at the hypothalamic-pituitary level (Scaramuzzi et al., 1977; Van Look et al., 1978; Scaramuzzi et al., 1980a). Immunization against androstenedione increases the frequency of luteinizing hormone (LH) discharges and mean levels of LH in ewes (Martensz, Baird, Scaramuzzi \& Van Look, 1976) in conjunction with increasing the number of follicles $>3 \mathrm{~mm}$ in diameter and ovulation rate (Scaramuzzi et al., 1980a). A lack of significant differences in peripheral androstenedione or oestrogen concentrations between immunized (Groups III and IV) and control (Groups I and II) heifers in this study may be related to the relatively low titres $(1: 100$ and $1: 1000)$ acquired in the short immunization period ( $<150$ days). The higher blood levels of steroids noted in ewes immunized against androstenedione or oestradiol is probably related to the high titres achieved (1:10 000; Martensz \& Scaramuzzi, 1979; Martensz et al., 1979; Scaramuzzi et al., 1980a). There are considerable differences in response of animals to active immunization procedures and these are not always related to high or low titres. At the titres noted in the antiandrostenedione group (mean $=16 \%$ binding at $1: 100$ dilution), ovulation was increased $29 \%$ and the number of non-pregnant heifers was not different from that in the controls. Intermediate titres of $1: 100-1: 1000$ can increase ovulation rate and avoid side effects leading to infertility in lamb flocks (Martin, Scaramuzzi, Cox \& Gherardi, 1979).

Lack of binding of $\left[{ }^{3} \mathrm{H}\right]$ androstenedione or $\left[{ }^{3} \mathrm{H}\right]$ oestradiol in fetal blood, allantoic or amniotic fluids denotes that the antibody did not cross the placenta. Binding of $\left[{ }^{3} \mathrm{H}\right]$ androstenedione (Group III) and $\left[{ }^{3} \mathrm{H}\right]$ oestradiol (Group IV) in the follicular fluid indicates that not only does the antibody pass into the follicle, but also still binds ${ }^{3} \mathrm{H}$-labelled steroids in vitro even after originating from an environment of exceedingly high steroid content in vivo.

Little is known of the physiological function(s) of ovarian androgens in the ewe (Baird, 1978) or cow (Wise et al., 1982b), but it has been suggested that ovarian androgens increase the rate of follicular atresia (Louvet, Harman, Schreiber \& Ross, 1975; Saiduddin \& Zassenhaus, 1978; Bagnell, Mills, Costoff \& Mahesh, 1982; Ware, 1982). Binding of androgens by the antibody in the follicle (follicular fluid) may help to reduce the rate of atresia and increase the pool of follicles developing to the ovulatory stage by alteration of the intraovarian concentrations of androgens. Follicular anti-androstenedione may decrease the effects of androgen on granulosa inhibin production (Henderson \& Franchimont, 1983) which would subsequently allow an overall increased stimulation of follicular development by gonadotrophins. Alternatively, the presence of the antibody in follicular fluid may produce even higher concentrations of follicular steroid concentrations. A possible functional significance has been attributed to binding proteins naturally found in the follicle in relation to the retention of steroids (Edwards, 1974; Fleming \& McGaughey, 1982). In actively immunized animals, the increased ovarian steroid production (oestrogen or androstenedione) may keep pace with the neutralizing capacity of the antibodies, resulting in a reduced, yet still partly effective, free hormone fraction. It is obvious that the mechanism is not as simple as the binding of antibody and elimination of circulating steroids (Martin, Scaramuzzi \& Henstridge, 1983). There is also a marked difference in the effects on the ovarian hypothalamic feedback system in relation to whether immunization is against oestrone or oestradiol and 
androstenedione or testosterone (Martensz \& Scaramuzzi, 1979; Scaramuzzi, Baird, Martensz, Turnbull \& Van Look, 1981; Cox, Wilson, Scaramuzzi, Hoskinson, George \& Bindon, 1982). It remains unknown whether the antibodies act as antihormones, bind the steroids and thus decrease the amount of steroid available to target tissues or decrease the clearance and increase the availability of steroid to the target tissues by acting as a type of mass action reservoir.

Increased progesterone levels in ewes immunized against androstenedione indicate possible binding to antibodies (Martensz \& Scaramuzzi, 1979) in conjunction with increased LH stimulation of steroidogenic activity. Although there was a trend for CL weight and progesterone levels to be higher in the animals of this study immunized against androstenedione and oestradiol, no significant differences were noted when compared to controls.

Contrary to the increased ovulation rate noted in sheep immunized against oestrogens (Smith $e t$ $a l ., 1981)$ and the anovulatory response noted by Martin et al. (1978) in cattle, ovulation rate and calf numbers were comparable to the controls in the beef cattle immunized against oestradiol in this study. Antibodies to oestrogens do not completely neutralize all circulating oestrogens because oestrogenic effects on vaginal epithelium and endometrium are readily seen (Ferin et al., 1974; Hillier, Groom, Boyns \& Cameron, 1975) and animals immunized against oestradiol can still maintain pregnancy (Ferin, Raziano, Tempone \& Vande Wiele, 1970; Csapo, Dray \& Erdos, 1975; Kaushansky, Bauminger, Koch \& Linder, 1977; Nieschlag \& Wickings, 1978). Oestrogens have been reported to be higher in animals with higher titres in that they may be unavailable for clearance (Sundaram et al., 1973) or ovarian output of oestrogens is increased because of decreased feedback effects on gonadotrophins (Pant et al., 1978; Rawlings et al., 1978; Martensz et al., 1979; Scaramuzzi, Martensz \& Van Look, 1980b). The fact that the antioestradiol serum did not bind diethylstilboestrol and moxoestriol could be useful in studies to investigate the role of oestrogens in target tissues of animals in which the circulating oestrogens have been neutralized.

Mention of trade names or companies in this paper does not constitute an implied warranty or endorsement by the U.S. Department of Agriculture or the authors.

\section{References}

Abraham, G.E. (1974) Radioimmunoassay of steroids in biological materials. Acta endocr., Copenh., Suppl. 183, $1-42$.

Bagnell, C.A., Mills, T.M., Costoff, A. \& Mahesh, V.B. (1982) A model for the study of androgen effects on follicular atresia and ovulation. Biol. Reprod. 27, $903-$ 914.

Baird, D.T. (1978) Synthesis and secretion of steroid hormones by the ovary in vivo. In The Ovary, 2nd edn, vol. 3, pp. 305-357. Eds S. Zuckerman \& B. J. Weir. Academic Press, New York.

Chamness, G.C. \& McGuire, W.L. (1975) Scatchard plots: common errors in correction and interpretation. Steroids 26, 538-542.

Cox, R.I. \& Wilson, P.A. (1976) Effects of immunizing sheep to steroid oestrogens and phyto-oestrogens. $J$. Reprod. Fert. 46, 524, Abstr.

Cox, R.I., Wilson, P.A., Scaramuzzi, R.J., Hoskinson, R.M., George, J.M. \& Bindon, B.M. (1982) The active immunization of sheep against oestrone, androstenedione or testosterone to increase twinning. Anim. Prod. Australia 14, 511-514.

Csapo, A., Dray, F. \& Erdos, T. (1975) The biological effects of injected antibodies to estradiol-17 $\beta$ and to progesterone in pregnant rats. Endocrinology 97, 603614.
Edwards, R.G. (1974) Follicular fluid. J. Reprod. Fert. 37, 189-219.

Elsaesser, F. (1980) Effects of active immunization against oestradiol- $17 \beta$, testosterone or progesterone on receptivity in the female rabbit and evaluation of specificity. J. Reprod. Fert. 58, 213-218.

Elsaesser, F. \& Parvixi, N. (1977) Prepubertal active immunization against gonadal steroids: effects on estrus, ovulation and the oscillatory pattern of plasma LH and progesterone in the female pig. Acta endocr., Copenh., Suppl. 208, 107-108.

Ferin, M., Raziano, J., Tempone, A. \& Vande Wiele, R.L. (1970) The use of antibodies as a tool in studies in reproductive physiology. In Immunologic Methods in Steroid Determination, pp. 199-233. Eds F. G. Péron \& B. V. Caldwell. Appleton-Century-Crofts, New York.

Ferin, M., Dyrenfurth, I., Cowchock, S., Warren, M. \& Vande Wiele, R.L. (1974) Active immunization to $17 \beta$-estradiol and its effects upon the reproductive cycle of the Rhesus monkey. Endocrinology 94, 765776.

Fleming, A.D. \& McGaughey, R.W. (1982) A progesterone binding component in porcine ovarian follicular fluid. J. Endocr. 94, 69-76. 
Ford, S.P., Christenson, R.K. \& Ford, J.J. (1982) Uterine blood flow and uterine arterial, venous and luminal concentrations of oestrogens on Days 11,13 and 15 after oestrus in pregnant and non-pregnant sows. $J$. Reprod. Fert. 64, 185-190.

Goodfriend, T.L., Levine, L. \& Fasman, G.D. (1964) Antibodies to bradykinin and angiotensin: a use of carbodiimides in immunology. Science, N.Y. 144, 1344-1346.

Henderson, K.M. \& Franchimont, P. (1983) Inhibin production of bovine ovarian tissues in vitro and its regulation by androgens. J. Reprod. Fert. 67, 291298.

Hillier, S.G., Groom, G.U., Boyns, A.R. \& Cameron, E.H.D. (1975) The active immunization of intact adult rats against steroid-protein conjugates: effect on circulating hormone levels and related physiological processes. In Steroid Immunoassays, pp. 97110. Eds E. H. D. Cameron, S. G. Hillier \& K. Griffiths, Alpha Omega Alpha, Cardiff.

Kaushansky, A., Bauminger, S., Koch, Y. \& Linder, H.R. (1977) Endocrine and reproductive repercussions of immunization against progesterone and oestradiol in female rats. Acta endocr., Copenh. 84, 795-803.

Land, R.B., Morris, B.A., Baxter, G., Fordyce, M. \& Forster, J. (1982) Improvement of sheep fecundity by treatment with antisera to gonadal steroids. $J$. Reprod. Fert. 66, 625-634.

Louvet, J.P., Harman, S.M., Schreiber, J.R. \& Ross, G.T. (1975) Evidence for a role of androgens in follicular maturation. Endocrinology 97, 366-372.

Martensz, N.D. \& Scaramuzzi, R.J. (1979) The plasma concentrations of luteinizing hormone, follicle-stimulating hormone and progesterone during the breeding season in ewes immunized against androstenedione or testosterone. J. Endocr. 81, 249-259.

Martensz, N.D., Baird, D.T., Scaramuzzi, R. J. \& Van Look, P.F.A. (1976) Androstenedione and the control of luteinizing hormone in the ewe during anoestrus. $J$. Endocr. 69, 227-237.

Martensz, N.D., Scaramuzzi, R.J. \& Van Look, P.F.A. (1979) Plasma concentrations of luteinizing hormone and follicle-stimulating hormone during anoestrus in ewes actively immunized against oestradiol-17 $\beta$, oestrone or testosterone. $J$. Endocr. 81, 261-269.

Martin, T.E., Henricks, D.M., Hill, J.R., Jr \& Rawlings, N.C. (1978) Active immunization of the cow against oestradiol-173. J. Reprod. Fert. 53, 173-178.

Martin, G.B., Scaramuzzi, R.J., Cox, R.I. \& Gherardi, P.B. (1979) Effects of active immunization against androstenedione or oestrone on oestrus, ovulation and lambing in Merino ewes. Aust. J. exp. Agric. Anim. Husb. 19, 673-678.

Martin, G.B., Scaramuzzi, R.J. \& Henstridge, J.D. (1983) Effects of oestradiol, progesterone and androstenedione on the pulsatile secretion of luteinizing hormone in ovariectomized ewes during spring and autumn. $J$. Endocr. 96, 181-193.

Nieschlag, E. \& Wickings, E.J. (1978) Biological effects of antibodies to gonadal steroids. Vitams Horm. 36, 165-202.
Pant, H.C., Dobson, H. \& Ward, W.R. (1978) Effect of active immunization against oestrogens on plasma gonadotrophins in the ewe and the response to synthetic oestrogen or LH. J. Reprod. Fert. 53, 241248.

Rawlings, N.C., Kennedy, S.W. \& Henricks, D.M. (1978) Effect of active immunization of the cyclic ewe against oestradiol-17ß. J. Endocr. 76, 11-19.

Saiduddin, S. \& Zassenhaus, H.P. (1978) Effect of testosterone and progesterone on the estradiol receptor in the immature rat ovary. Endocrinology 102, 1069-1076.

Scaramuzzi, R.J. (1975) Inhibition of oestrous behaviour in ewes by passive immunization against oestradiol173. J. Reprod. Fert. 42, 145-148.

Scaramuzzi, R.J., Davidson, W.G. \& Van Look, P.F.A. (1977) Increasing the ovulation rate of sheep by active immunization against an ovarian steroid, androstenedione. Nature, Lond. 269, 817-818.

Scaramuzzi, R.J., Baird, D.T., Clarke, I.J., Martensz, N.D. \& Van Look, P.F.A. (1980a) Ovarian morphology and the concentration of steroids during the oestrous cycle of sheep actively immunized against androstenedione. J. Reprod. Fert. 58, 27-35.

Scaramuzzi, R.J., Martensz, N.D. \& Van Look, P.F.A. (1980b) Ovarian morphology and the concentration of steroids, and of gonadotrophins during the breeding season in ewes actively immunized against oestradiol-17ß or oestrone. J. Reprod. Fert. 59, 303310.

Scaramuzzi, R.J., Baird, D.T., Martensz, N.D., Turnbull, K.E. \& Van Look, P.F.A. (1981) Ovarian function in the ewe after active immunization against testosterone. J. Reprod. Fert. 61, 1-9.

Scatchard, G. (1949) The attraction of proteins for small molecules and ions. Ann. N.Y. Acad. Sci. 51, 660-672.

Smith, J.F., Cox, R.I., McGowan, L.T., Wilson, P.A. \& Hoskinson, R.M. (1981) Increasing the ovulation rate in ewes by immunization. Proc. N.Z. Soc. Anim. Prod. 41, $193-197$.

Sundaram, K., Tsong, Y.Y., Hood, W. \& Brinson, A. (1973) Effect of immunization with estrone-protein conjugate in rhesus monkeys. Endocrinology 93, 843847.

Van Look, P.F.A., Clarke, I.J., Davidson, W.G. \& Scaramuzzi, R.J. (1978) Ovulation and lambing rates in ewes actively immunized against androstenedione. J. Reprod. Fert. 53, 129-130.

Ware, V.C. (1982) The role of androgens in follicular development in the ovary. I. A quantitative analysis of oocyte ovulation. J. exp. Zool. 222, 155-167.

Wise, T.H., Caton, D., Thatcher, W.W., Barron, D.H. \& Fields, M.J. (1982a) Ovarian function during the estrous cycle of the cow: ovarian blood flow and progesterone release rate. J. Anim. Sci. 55, 627-637.

Wise, T.H., Caton, D., Thatcher, W.W., Leher, A.R. \& Fields, M.J. (1982b) Androstenedione, dehydroepiandrosterone and testosterone in ovarian vein plasma and androstenedione in peripheral arterial plasma during the bovine oestrous cycle. J. Reprod. Fert. 66, 513-518. 